\title{
FROM VALUED STAYERS TO WORKING HANDS? THE SOCIAL CONSEQUENCES OF CHANGING EMPLOYMENT RELATIONS AMONG POLISH MIGRANTS IN FARMED SALMON INDUSTRY IN RURAL NORWAY
}

Jakub Stachowski, Bente Rasmussen ${ }^{1}$

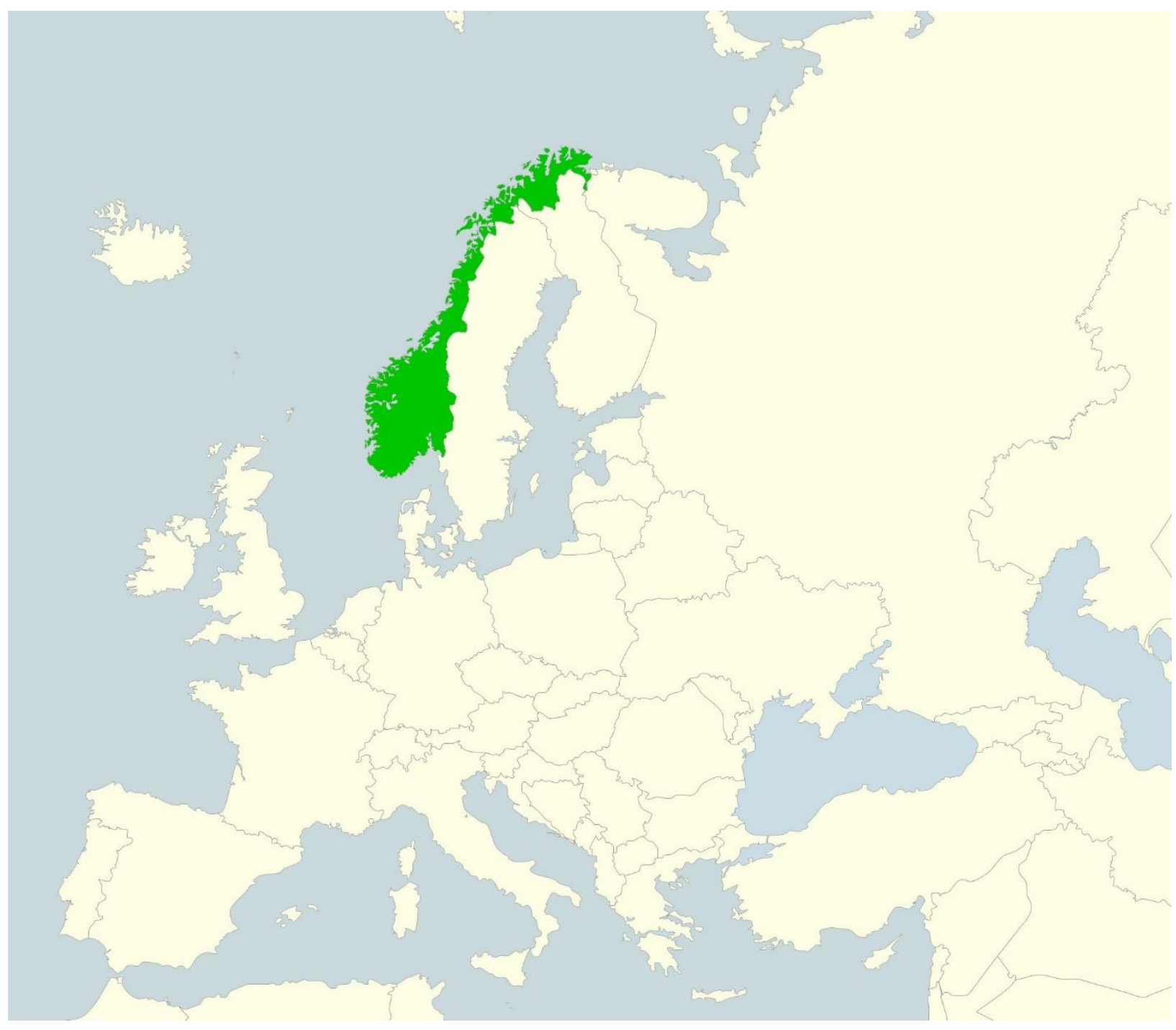

1 Jakub Stachowski, Ph.D-candidate, email: jakub.stachowski@ntnu.no, ORCID: 0000-0001-8243-8863, Bente Rasmussen, Professor Emeritus, email: bente.rasmussen@ntnu.no, ORCID: 0000-0002-8164-6350, Department of Sociology and Political Science, Norwegian University of Science and Technology, Trondheim, Norway. 
Abstract: International migrant workers in European rural regions have supplied rural industries with necessary labour, stimulated the demography of host communities and raised questions about the inclusion of migrants. Using the case of Polish post-accession migrants employed in the farmed salmon industry in rural Norway, we explore the social consequences of changing employment relations in rural industries. By using a temporal perspective, we identify a transition from an inclusive employment regime experienced by the migrants who arrived in the locality within the first years after the EU enlargement in 2004, to an increasingly exploitative, insecure and competitive work environment for recently arrived migrants. We emphasise how employment conditions offered to different 'waves' of migrants affect the ways they perceive their status and value in rural hosting communities. Ultimately, we reflect on the potential long-term consequences of international migration to rural areas.

Keywords: labour migration, rural areas, Poland, Norway, employment relations

Sammendrag: Arbeidsinnvandrerne som kom til rurale områder i Europa, møtte arbeidskraftbehovet til lokal industri og førte til befolkningsvekst i distrikter som var truet av fraflytting. Innvandringen førte også til spørsmål om innvandrernes inkludering i lokalsamfunnet. Artikkelen undersøker sosiale konsekvenser av endringer $i$ ansettelsesforhold for innvandrere i et lokalsamfunn basert på intervjuer av polske arbeidsinnvandrere som kom til Norge etter EU-utvidelsen i 2004 og ble ansatt i den lokale lakseindustrien. Vi viser hvordan ansettelsespolitikken endret seg fra en inkluderende praksis for de tidlige innvandrerne til en mer usikker og konkurransepreget arbeidskultur. Forskjellene i behandlingen av arbeidsinnvandrerne som kom til lokalsamfunnet på ulike tidspunkt etter 2004, førte til et skille mellom 'gamle' og 'nye' innvandrere som utfordret innvandrernes syn på sin posisjon, verdi og framtid i lokalsamfunnet.

Nøkkelord: arbeidsinnvandring, rurale områder, Polen, Norge, ansettelsesforhold

Streszczenie: Międzynarodowi migranci zarobkowi dostarczyli europejskim obszarom wiejskim niezbędnej siły roboczej, wpłynęli pozytywnie na lokalne procesy demograficzne, rodząc tym samym pytania dotyczące włączenia migrantów do lokalnych społeczności przyjmujących. W artykule analizujemy społeczne konsekwencje zmian w stosunkach pracy w przemysłach wiejskich, opierając się na wywiadach z polskimi migrantami poakcesyjnymi w jednej z gmin przy norweskim wybrzeżu, zatrudnionymi przy przetwórstwie łososia hodowlanego. Korzystne warunki pracy oferowane migrantom zatrudnionym w pierwszych latach po akcesji Polski do UE w 2004 roku, zmieniły się na niekorzyść dla nowo przybyłych pracowników, rodząc w nich poczucie niepewności, doświadczenie wyzysku i konkurencji, oraz wpływając na to jak postrzegają swoją pozycję w społeczności przyjmującej. Artykuł podejmuje refleksję dotyczącą długoterminowych konsekwencji międzynarodowych migracji zarobkowych na obszary wiejskie.

Słowa kluczowe: migracje zarobkowe, obszary wiejskie, Polska, Norwegia, stosunki zatrudnienia

\section{Highlights:}

- The employment-inclusion nexus of international labour migrants is dynamic.

- Different 'waves' of labour migrants encounter different employment conditions.

- Inclusive employment relations become competitive and insecure over time.

- They make migrants doubt their value and position in the receiving community. 


\section{Introduction}

International migration to rural areas in many European countries has been viewed as a significant driver for rural social change and as a 'demographic refill' (Hedberg and Handrikmann, 2014) for declining rural communities (Bayona-i-Carrasco and Gil-Alonso, 2013; Green et al., 2009; MorénAlegret and Wladyka, 2020). Profoundly transformed and restructured by increasing globalisation and urbanisation, rural industries have struggled with the unavailability of local labour, creating thus a demand for a cheap and flexible labour force from abroad (Corrado et al., 2016; DuftyJones, 2014; Rye and O'Reilly, 2021). On the other hand, the arrival and presence of international labour migrants in rural regions have raised questions concerning their long-term engagement, status, and impact on the receiving rural communities (Jentsch and Simard, 2009; Woods, 2018).

The EU-enlargements in 2004 and 2007 and inclusion of the Eastern and Central European countries created migration opportunities for the new EU-citizens and for employers in receiving states to recruit the desired manpower (Recchi and Triandafyllidou, 2010). The waves of migration from the countries included have been of significant magnitude and with time developed a considerable complexity (Grzymała-Kazłowska and Phillimore, 2019; Sert, 2018). They encompass a variety of migration strategies and tendencies toward the long-term settlement of the migrants (Bygnes and Erdal 2017; Piętka-Nykaza and McGhee 2017) and reveal a geographic proliferation of the migrants into typically non-traditional contexts such as rural and small-town areas (Jentsch, 2007; McAreavey, 2017; Scott and Brindley, 2012).

Numerous studies have mapped out the situation of post-accession migrants in rural receiving areas. Most of the studies have examined seasonal labour migration to the agricultural and horticultural sector (de Lima and Wright, 2009; Fiałkowska, 2019; Moore, 2021), but notable exceptions include tourism, construction, and the meatpacking industry (Piso, 2016; Knight et al., 2014; Lever and Milbourne, 2017). Whilst the existing analyses identify various facets of relationships between the context of rural labour markets and the position that international migrants occupy in rural host communities, they have seldom employed an explicit temporal perspective (among the exceptions are Findlay and McCollum, 2013; Piso, 2016; Rye, 2018). More than 15 years after the 2004 EU-enlargement, we view it as timely to engage in such analysis in order to understand the phenomenon from a longer-term perspective. We draw on a case of Polish post-accession labour migrants in a rural-coastal municipality in Norway who are employed by the local farmed salmon producer $^{2}$. Farmed salmon has become a globally recognised Norwegian export product and a bedrock of the country's economy. Whilst growing exponentially and generating high revenues, the industry met challenges concerning the supply of labour for manual jobs in the salmon processing plants, typically located in rural-costal municipalities. The EU-enlargements in 2004 and 2007 and migration to Norway they triggered, have proven to meet those challenges (Aure et al., 2018; Friberg and Midtbøen, 2018; Slettebak and Rye, 2020).

Polish labour migrants in this study arrived in a remote rural municipality in Norway to work on the production line in the processing plant of a major farmed salmon producer who is also the main employer in the locality. Our analysis builds on 23 research interviews with 29 Polish migrants who work for the company or had worked there earlier. Over the years, the company has been expanding its production and built a new more effective processing plant, increasing the number of foreign workers, whilst the work conditions for the labour migrants have deteriorated. Significantly, the all-year-round production of the salmon creates a need for a permanent workforce, which facilitated a long term-engagement of many of the Polish migrants who participated in this study. Our goal is to retrace the developments in their work conditions to shed light on the impact they have had on the migrants' perception of their position and future in the local community. Based on the narratives of the Polish migrants, their reflections and experiences, our inquiry contributes to the literature on international rural migration by providing insights into the changing dynamics of employment relations in rural industry and their impact on

\footnotetext{
2 The article expands and elaborates on the first author's earlier discussions on post-accession labour migration to rural Norway, drawing on the same data (see Stachowski 2020 and Stachowski and Fiałkowska, 2021). Whilst these publications analysed work-related aspects as one of several aspects that affect the situation of the migrants locally, the current article focuses exclusively on the analysis of the employment relations.
} 
migrants locally. Drawing on literature that conceptualises labour migration, we explore the following research question:

What implications have the changes in employment relations had on the migrants' perceptions of their position in the local community?

This article has the following structure: we start by presenting theoretical perspectives on labour migration. Then, we introduce the Norwegian context of post-accession migration. Subsequently, we present our data and discuss our fieldwork and the setting. Our analysis comprises three subsections that discuss 1 ) the development of the company and the changing character of work, 2) the consequences of the changing employment relations, and 3) the implications of the ethnically divided workplace. In the final section, we address the broader contribution of the article to the literature on international migration to rural areas.

\section{Perspectives on labour migration}

The dynamics underlying the phenomenon of labour migration are complex. The archetypical picture of a labour migrant is of an individual who follows a unidirectional route from a less to a more developed country, seeking the improvement of her financial situation (Piore, 1979). Labour migrants provide a source of cheap, flexible labour that satisfies the demand in specific industries in receiving countries. The classic depiction underscores the willingness of migrant workers to engage in work that the natives are not inclined to perform, at least not for the pay offered (Piore, 1979). Labour migrants have been viewed as a 'reserve army of labour' responding when necessary to the demand of the capitalist logic of production and playing a central role in the accumulation of capital in the host countries (Castles and Kosack, 1972; Rye and Scott, 2018). From the 'utilitarian' perspective, labour migration may be understood as a way of outsourcing the costs of production and reproduction of labour to migrants' home countries (Burawoy, 1976; Décosse, 2004). Some scholars have argued that labour migration is a triple win as it may decrease unemployment rates in migrants' home countries, satisfy the demand for labour in receiving countries, and improve the status and material situation of migrating individuals (Vandenberg, 2015). Nevertheless, labour migrants are frequently depicted as disempowered, belonging to a broad category which Standing (2011) has called 'precariat'. They typically occupy positions in the so-called 'second segment' of the labour market where, in general, work arrangements deviate from the standard contract at work and increase migrants' vulnerability and sense of insecurity (Pajnik, 2016; Piore, 1979). Furthermore, labour migrants have commonly been viewed as inclined to accept such substandard working conditions because they evaluate their situation through the prism of their home countries (Nieswand, 2006; Piore, 1979). This means that despite the precarity of their labour market situation in host countries, the conditions may still be perceived and rationalised as more advantageous when compared with home country standards. Other studies have challenged this perspective by showing that migrants continually reevaluate their situation and, with time, the significance of the home country may weaken (Piso, 2016).

Sayad (2004) has observed that the ability to work is a defining feature of a labour migrant that legitimates her presence and status in a host society. The 'utility' value of labour migrants stems from their reputation for exhibiting an exceptional work ethic, fitting 'naturally' into particular types of jobs, and as docile people willing to accept difficult working conditions (Friberg and Midtbøen, 2017; Holmes, 2013; MacKenzie and Forde, 2009; deLima and Wright, 2009). Sometimes, the specific stereotypes associated with ethnic groups may also be used by the migrants belonging to those groups as bargaining assets in negotiations during the job-seeking process (Friberg, 2012a).

Rural areas display considerable international and regional variation, and national contexts and policies regulating labour markets are key aspects in understanding the inclusion of migrants in rural areas (Bock et al., 2016; de Lima 2012). Rye and Scott (2018:934) have suggested four elements of employment relations that may explain the situation of the migrants in rural labour markets: 1) the duration of employment, most notably seasonal vs. non-seasonal, 2) degree of informalisation, that is the extent to which migrants' legal employment entitlements are fulfilled by the employer, 3) direct or indirect forms of employment with the former being considered more 
secure than the latter, and 4) forms of remuneration, for instance, piece-rate versus weekly or monthly payment. These aspects are crucial for our discussion and will help to frame the longterm perspective on international migration and the development of labour relations in the salmon company under study. To cast light on changes in employment relations, we use the concept of the social contract at work, which denotes the unwritten agreement between employer and employees regarding the reciprocal expectations between the parties, such as the short- or longterm perspective of employment, predictability of work, or various forms of gratification for workers' commitment (Gouldner, 1960; Rousseau, 1995). The concept resonates with studies that have shown that migrants' position in the host society's labour market and the degree of stability, safety and predictability it offers, is a key aspect affecting their decision for family reunifications and settlement (Bygnes and Erdal, 2016; Flynn and Kay, 2017; Friberg, 2012b; Ryndyk, 2020). The above speaks to other studies that suggest that for some migrants, moving abroad is a quest for 'normal life' that they haven't been able to achieve in their home countries (i.e. Rabikowska, 2010; McGhee et al.,2012).

The above perspectives provide a multi-angled framework for the analysis of the changing employment relations for the Polish labour migrants in the farmed salmon industry in a rural area in Norway and allow for reflections upon the position migrants occupy in the host rural community.

\section{The context of post-accession migration to Norway}

Norway is not a member of the EU, but, through its membership in the European Economic Association, it maintains close cooperation with the EU. As such, the country participates in a common policy of flow of capital, services, labour, and people within the EEA territory. After the EU-enlargements in 2004 and 2007, Norway received a large number of migrants from the new member states. Poles, including children, have quickly become the largest group, today counting roughly 115,000 registered persons, over 65,000 more than the second-largest group, the Lithuanians (Statistics Norway, 2020). Many Poles have been attracted to Norway by comparatively good employment prospects, high wages, and a generally high standard of living, but also by possibilities for family reunification (Gmaj, 2016). Considered predominantly labour migrants, Poles tend to concentrate in specific industries, such as construction, production, various services, or agriculture (Eldring and Friberg, 2013).

Significantly, the settlement policy affecting the EU migrants in Norway grants them freedom of settlement in the country's entire territory. Post-accession migrants from Central and Eastern Europe have spread into many regions outside the main cities, and their presence there is, first and foremost, explained by the work opportunities locally available (Rye and Slettebak, 2020; Søholt et al,. 2016).

The arrival of a large number of post-accession labour migrants to Norway generated a 'supply shock' for Norwegian employers (Friberg, 2016). The sudden appearance of the relatively large number of labour migrants in the Norwegian labour market, therefore, raised questions of the consequences for the Norwegian model of working life. In the Norwegian context, the security of employment through full-time permanent positions has traditionally been the basic element of the standard employment relation, built upon a power balance between organised labour and employers (Barth et al., 2014). Whilst worldwide the tendencies toward the use of non-standard employment have surged (ILO, 2016), Norway has maintained the principle of offering permanent employment to workers. Reports of work conditions amongst the migrants, below Norwegian standards, have led to a range of institutional responses aimed at countering these disturbing developments. Amongst these responses has been the extension of collective bargaining arrangements in several industries to include all the employees regardless of the type of employment (which since 2016 also include the fish industry), the Temporary Agency Work Directive, and workers' unions campaigns aimed at the recruitment of new members from among the migrants (Friberg, 2016). 


\section{Data and setting}

This article is part of the first author's doctoral project that studied processes of integration of international labour migrants in rural areas in Norway. The data for the project were collected during several intensive ethnographic stays in the locality between May 2016 and May 2018. During the fieldwork, the first author conducted a total of 30 in-depth interviews with 36 Polish labour migrants and engaged in participant observation among them. The analysis in the article is based on a sub-sample of 23 interviews with 29 informants who worked for the local salmon producer at the time of the interview or had worked there previously.

The Polish migrants who were interviewed were approached predominantly through two gatekeepers, but some were also recruited through snowballing. During the recruitment, the aim was to engage participants with heterogeneous backgrounds in terms of age, gender, and time spent in the locality. The final sample is fairly gender-balanced (13 women and 16 men). The participants' duration of stay in the municipality ranged from approximately 2 to 13 years (6.5 years on average). 22 interviewees had secondary education and seven had higher education that they had received in the home country.

The interviews were conducted by the first author in the interviewees' mother tongue. These interviews followed a biographical outline and aimed at capturing migrants' experiences over time (Roberts, 2002). They touched upon several topics, such as the circumstances of the arrival in the region, social relationships, the migrants' experiences of the rural place, their contacts with the home country, plans for the future, and various barriers and possibilities for integration locally. Given the fact that work was the main driver behind many migrants' arrival in the region, interviews included thorough discussions concerning the work and conditions of work.

In addition to the interviews, the fieldwork also included observations with a variable degree of participation, as well as informal conversations with persons encountered accidentally. The observations were mostly carried out during various events arranged by the local Polish community. Of particular importance is the fact that the first author participated in guided tours to fish farms and was shown around the local plant by the gatekeepers. This contributed to nuanced insights into the nature of the work performed by the migrants. It must be stressed that this article draws exclusively on the perspectives of the migrants and, as such, leaves voices of other actors such as employers, union representatives, or local authorities unheard. We are aware that inquiring into their standpoints could have offered a different picture to the one that we present here.

During the fieldwork, issues of anonymity, confidentiality, and trust were recurring concerns. The local Polish community turned out to consist of around 200 individuals and revealed a high degree of social visibility. Discussions about the workplace and conditions of work proved to be at times sensitive. To assure the confidentiality of the participants, we assigned them participant numbers, with specifications of age and gender. We also changed slightly some of the facts revealed in the discussions about work and decided not to reveal the municipality's name.

This study is based on a single case. In this study, by case, we understand the region, the type of migration (in this case, labour migration to rural areas), and the type of industry, here represented by the local salmon producer, the main employer in the locality. These three aspects are interrelated.

The location studied is an island located off the Norwegian coast. It takes approximately two and a half hours to reach the island by car or ferry service from the nearest city. The residential structure of the island comprises a single municipality-centre, encompassing most of the public and private services, and many villages and smaller settlements. The housing structure consists almost exclusively of detached houses. For many years, the community has been experiencing a decrease in the number of Norwegian-born inhabitants. Since the EU-enlargement in 2004 and 2007 , the booming local farmed salmon production has attracted a large number of migrants from the new member states. Since then, the share of the foreign-born population has grown from a very few to represent approximately $25 \%$ of the local population, causing the overall size of the population to increase exponentially. Whilst the location hosts migrants from almost 50 countries, the largest migrant groups are Poles, Lithuanians, Bulgarians, and Estonians. 
The relatively stable, year-round demand for labour in the salmon industry has facilitated a longterm engagement of many of them.

\section{Analysis}

In this section, we discuss three themes: 1) the development of the company and the changing character of work performed by the migrants, 2) the consequences of the changing social contract at the workplace for the migrants, and 3) the implications of the ethnically divided workplace for the migrants.

\section{From a local enterprise to a behemoth}

A great majority of the Polish migrants in this study arrived in the region drawn by the work opportunities in the local salmon industry. Many described the moment of arrival in terms of a wish to improve their overall life quality, by which they meant mainly the financial aspect. However, many desired also more general life-changes which often coincided with turning points in their life trajectories, such as coming of age, finalising or interrupting education, establishing a family or having children. When interviewed, the Polish migrants were at different phases of migration and the narratives revealed a discernible difference between those who arrived in the region many years ago and those who arrived within the previous couple of years.

The early arrivals, that is those who moved to the municipality in the first years following the 2004 EU-enlargement, described ad-hoc recruitment practices arranged by the local salmon producer. The first Polish migrants arrived in the locality through individual intermediaries, viz., the few Polish migrants who already lived in the locality or nearby, who helped the plant owner to identify potential workers in Poland. These early employment practices were largely improvisatory for both the employer and the migrants, who often had to decide whether to accept the job offer on short notice. However, high incentives for both the industry and the migrants made these practices feasible. In this initial phase, the Polish migrants discussed the employer's eagerness to offer people a job and give them permanent fulltime contracts after only a short trial period. One of the informants recalled the circumstances of his arrival and employment at the processing plant:

So, the three of us arrived, we visited the plant, but they [people who worked for the company] didn't have time to talk to us. They told us to come back on Friday. We showed up on Friday and they didn't say anything about any job offer or anything else. They simply started to show us around the company, telling us how things work here and at the end they gave us contracts to sign. So, we didn't even know at first whether we got the job or not. I thought to myself: what is this guided tour all about? But then they told us to show up at work at 8 a.m. on Monday. So that's how it was.

Informant 17, male, 40s 13-years in the industry

The reminiscence quoted above demonstrates a generally welcoming climate of reception and the undemanding attitude of the employer in offering work to those who wanted it. Employers who use foreign workers resort to various recruitment practices to supply the necessary manpower. Such practices may involve a mix of formal and informal solutions adjusted to specific conditions and demands (Findlay and McCollum, 2013), and target specific national groups who are believed to possess the desired qualities (Findlay et al., 2013; Friberg and Midtbøen, 2017). As reported by the interviewees, whilst the initial recruitment strategies demanded a demonstration of a strong work ethic and commitment, they were rather effortless. Permanent contracts were granted automatically after the trial period, and foreign language skills were not a relevant issue. The company has always used an internal, informal recruitment system, requesting established and trusted employees to suggest potential new workers from their social networks. The vacancies were not announced publicly but spread by word of mouth and all employees were hired directly by the company.

Throughout its 30 years of operation, the company has been growing and expanding its production capacity. Evolving from a small local enterprise to a significant actor in the global salmon market, it established branches in Norway and other countries and developed a global 
network of contractors and customers. Despite the global outreach, the company remained embedded locally, symbolised by its headquarters being located there. The growth of the company was accompanied by an increase in the number of employees, a majority of whom are of foreign origin. As a result, the company's labour force has become international and comprises nearly 20 nationalities, with Poles, Lithuanians, Bulgarians, and Estonians being the largest groups. Hardy (2017:26) observes that the restructuring and reorganisation of companies reflect the changing dynamics of capitalism. Throughout the last decades, rural areas and their industries have been integrated into and transformed by broader global processes. The development of the Norwegian salmon industry and its dependence on foreign workers demonstrates the simultaneity of the global economic and social interconnections in rural areas (Hedberg and do Carmo, 2012; Woods, 2007).

Adding to the above, significant game-changing events in the company's history have been the launch of a new processing plant and listing on the stock exchange some years ago. Many informants reflected on these changes and their implications for the organisation of work and the treatment of the workers:

(...) you can't compare how it was when I started with how it is right now. There was no rush. Workers were respected. Now they don't give a shit about them, because they can be replaced by others. We received permanent contracts after one year, automatically. Now people get trash contracts.

\section{Informant 3, man, 60s, 11 years in the industry}

When looked at retrospectively, the informants discussed the changes in the company's employment policy and work organisation. The production process at the new plant has been highly rationalised and the tasks deskilled. The introduction of cutting-edge technological solutions has transformed work routines and affected social relations at work with the consequence that work has become more depersonalised - as one of the first couples to arrive related:

He: [The company] has become a corporation, a behemoth. The thinking is different now. Now they think only about numbers. Besides that, a lot has changed between the workers.

She: In the old plant, we worked close to each other, next to each other. We could see each other, we could talk.

He: People were helping each other. One was helping the other.

Informants 5 and 6 , a married couple, 30s, 11 years in the industry

In the words of interviewees, the development of the company was accompanied by increased attention to higher profits and saving costs. This was reflected in the work environment and the relations between the workers. The new processing technology was introduced to ensure maximum efficiency and the high tempo of processing made the work physically demanding and dull. The plant is divided into slaughtering, filleting, and packing departments, and the production comprises a sequence of repetitive and very specific and precise tasks which, typically, engage only certain parts of workers' bodies. The plant has a processing capacity of between 100 and 200 fish per minute, which permits the processing of 150,000 tons of fish during an ordinary twoshift workday.

\section{Between (in)security and discipline- changing social contracts at work}

In the interviews, our informants reflected on their early days in the company. When the first migrants arrived in the locality, the worker-employer relations were not limited to what was stated in the written contract. Recollections of the first arrivals illustrate how the employer was willing to facilitate the everyday parental responsibilities in cases of young couples considering a longer stay:

He: We have to admit that it is ok with the company when it comes to children. 
She: We have a daughter who goes to kindergarten and we have to deliver her (to the kindergarten). We have only one car and conditions don't always allow my husband to take care of it.

He: My wife can work from [specific hour] -to [specific hour], meaning that she doesn't have to work shifts. She works whilst the kindergarten is open. (...) But not everybody likes that. You know, the more people there are the.... But there are those who are the 'old sort' and we are the 'old sort'... the company's attitude to us is slightly different. And when our daughter was born, and my wife came back to work after maternity leave, it was clear that she would work only during the kindergarten's hours of operation.

Informant 24 and 25, a married couple, 40s, 11 years in the industry

In the extract quoted above, the informants distinguish between 'new' and 'old' workers, implying that the latter category was more privileged. It reflected a social contract at work comprising a long-term relationship between the employer and the migrants that offers mutual considerations and reasonable conditions in exchange for their effort (Rousseau, 1995). Several markers of belonging to the category 'old' emerged in the interviews, suggesting that the migrants who arrived early on, felt appreciated and recognised as more than just workers. Apart from what the company did to make family life easier, some of the migrants mentioned being greeted by the company's owner by name. Such practices had implications in terms of migrants' feelings of self-worth and well-being and played an important role in how they experienced and perceived their relationship with the company and their position in the locality.

Along with the aforementioned development of the production facilities and the automation and rationalisation of the production process, the company introduced new employment practices. In contrast to the earlier practice of offering full-time employment after a 6-month trial period, the current policy, as revealed by those interviewed, consisted of a one to two-year-long series of trial-periods during which the company operated with short-time contracts extended every few months. These trial periods could then be followed by an offer of permanent employment, but for no more than $80 \%$ of the standard full-time job. The stories told by the migrants who arrived first and those who were employed after the new plant had been launched, therefore differed substantially to those related by workers with shorter tenure. Whilst work on the processing line is equally demanding for everybody, the migrants who arrived in the locality relatively recently, have interpreted the practice of $80 \%$ contracts as unfair.

On-call and short-term contracts during the lengthy trial period generated feelings of instability and unpredictability amongst the migrants. These conditions affected their everyday lives and had implications for the planning of the near and distant future in the locality. A young, relatively newly arrived woman without a permanent contract emphasised the following:

The company has always been considered one of the best [in terms of work conditions]. They invest in people, give them a course and so on. They want people to stay all year round. But the conditions of work have deteriorated. Before they used to employ people quickly on permanent contracts, now it is not that easy, they use on-call contracts. (...) I work today but I don't know how it is going to be tomorrow. It is hard to plan. I simply can't plan anything. (...) I want to stay here and live. (...) when you have a permanent contract (...) everything is more settled. If you endure one year, you might get a contract, but I am fed up already.

\section{Informant 20, female, 30s, 2 years in the industry}

The quotation illustrates two important issues. First, it demonstrates a general sense of insecurity experienced by some of the migrants and suggests that the conditions of employment were not clear, as the interviewee was expecting a contract she eventually did not receive. Second, it conveys the expressed desire of the interviewee to stay in the locality, despite the recency of her arrival. The insecurity of her current situation made the realisation of this plan difficult. Although migrants' decision to stay is affected by multiple factors (Lynnebakke, 2020), the above testimony illustrates the key role that work and working conditions play in migrants' considerations of a longer-term stay in the host countries and localities (Friberg, 2012; Knight et al., 2014). It also problematises the conventional understanding of labour migration as primarily financially oriented. 
Whilst for many of our interviewees migration was economically motivated, their narratives challenge the assumption about the alleged willingness to accept precarious working conditions because they were better than those in their home country (Nieswand, 2011; Piore, 1979). From the employers' perspective, however, assumptions about migrants' relative financial gains may serve as a legitimation of the precarious conditions and invalidate migrants' claims to better treatment (Rye and Scott, 2021). The foregoing does not mean that the comparisons with the home country's work conditions were absent. On the contrary, the interviewees appreciated both the possibility of improving their material situation and achieving a better work-life balance. Significantly, none of the interviewed migrants complained about the wage level, which for a production worker is a guaranteed minimum of 183 Norwegian kroner an hour ${ }^{3}$ (approximately 20 USD or 18€) (The Norwegian Labour Inspection Authority, 2020). At the same time, the interviews revealed a sense of ambivalence amongst many participants who were far from satisfied with the conditions they experienced. This has been a recurring theme amongst relatively new migrants, who were critical of the practices of the factory management. Comparisons of the narratives of the recently arrived and the 'old' migrants, reveal an important change in the social contract at work as exemplified in the following reflection from a male migrant:

First, you have to work for two years to get a permanent contract. You have 3-month or 1- month contracts. After that, you get a permanent one, an $80 \%$ contract with a 6-month trial period. I arrived here (in Norway) hoping for something different, but a lot for me is the same [as it was in Poland]. This system makes you insecure. It gives people the feeling that if they don't work hard, they are not good enough. They squeeze them like lemons for 2 years, and then people can't work properly after they get the permanent contract. They are too exhausted after the two-year struggle for the contract.

\section{Informant 28, 30s, 6 years in the industry}

The practice of hiring the workers on a series of short temporary contracts left the workers feeling insecure whilst hoping for a permanent job. However, when a lengthy trial-period was followed by only an $80 \%$ contract, the migrants experienced a state of 'permanent temporariness' (Rasmussen and Håpnes, 2012). These exploitative practices took place as the migrants struggled to prove their value, sacrificing their health and well-being whilst expecting gratification in the form of a fulltime contract. Discipline and insecurity were mentioned as important aspects of employment relations. As argued by Smith (1999), self-discipline is an efficient indicator in the recruitment process as it allows managers to distinguish between potentially 'reliable' and 'unreliable' candidates.

Our informants also described how Norwegian managers engage in Taylorist practices such as the use of a stopwatch to measure the number of fish processed per minute and complaints about the low efficiency of the migrants' work. One of the informants said that it felt like he was being treated like a 'nigger', referring to the history of slavery in the US. The lack of gratification in the form of a full-time contract was seen as a breach of the principle of reciprocity (Gouldner, 1960). This treatment was experienced by the migrants as exploitative and made them feel undervalued.

Whilst most of the migrants interviewed as part of this project occupied positions that did not require any formal qualifications, some had been promoted to positions that included productionplanning or supervision. Although such promotions presupposed more stress in the work day, they were interpreted by the migrants as an acknowledgement of their earlier engagement and high-quality performance. Being promoted offered a sense of security generated by the recognition of one's competence and suggested that one's qualifications were not easily replaceable. Nevertheless, such promotions did not mean full-time employment either. One of the Polish migrants who was promoted to a supervisory position reflected upon this issue:

\footnotetext{
${ }^{3}$ For comparisons, the hourly wage in other migrant-labour intensive sectors are: construction - 209/hour; agriculture and holticulture - 123/hour (seasonal workers); cleaning workers, 187/hour; Hotel, restaurants and catering - 168/hour (The Norwegian Labour Inspection Authority, 2020).
} 
So they [the company] protect themselves. If you have a 100\% contract, they can send you home, but if you don't agree, they have to find something for you to do. But if you have $80 \%$, they can send you home for a couple of hours. (...) The company is not that friendly towards people [workers]. They don't give you the feeling that they take care of people to the degree that [one] would expect. And it makes you have doubts. Many people say that.

I: What would give you stability, then?

First of all, a contract [offered] on their initiative, so that I don't have to fight for it. That would make me think that the company values me.

\section{Informant 22, man in 20s, 3 years in the industry}

A fulltime contract was regarded as of fundamental value for the migrants, and the treatment that confuted this assumption was considered unjust. Interestingly, the migrants were conscious of their underprivileged position and treatment, and, for some, it created doubts about their possible future in the locality. Whilst many of our interviewees have purchased houses in the locality, the quotation illustrates a link between the predictable work situation and plans to settle in the locality. One informant and his partner hesitated and changed their minds several times, but eventually decided not to settle. The insecurity at work that they experienced, played a key role in their decision. The $80 \%$ contract was perceived as the company's strategy to protect itself from fluctuations in the market and as a form of out-sourcing of the risk associated with market fluctuations from the employer to the workers (Kalleberg, 2011). Interestingly, this practice seemed absolute, even in instances where the number of hours worked during the year was equal to, or significantly exceeded, the standard yearly numbers of hours worked. As one of the informants suggested, the company stretched the law and did not offer a $100 \%$ contract even when the law dictated the rules explicitly ${ }^{4}$. Moreover, although labour unions are institutionalised in the Norwegian labour market (Barth et al., 2014) and present in the company, there was a low degree of collective organisation in the union among the migrant workers. On average, the interviewees considered the unions useless and were sceptical about the value of paying membership fees or reported being afraid of potential repercussions if they joined the union.

The growth of the company and the increase in production were made possible by a combination of technological innovation and stretching the physical abilities of the migrant workers. The migrants interviewed elaborated on complex employment mechanisms taking place amidst great competition for work. Their efforts to acquire permanent contracts took place in a competitive environment generated by a high supply of migrant workers. In such a context, many were willing to demonstrate their physical capability, inadvertently sending a signal that allowed the employer to increase the production norms. The struggle for permanent positions in the company took place under conditions over which the workers had little control. One of the female interviewees who had spent a couple of years in the industry before exhausting her health said the following:

(...) and the treatment... you have to... you have to [work] beyond your normal capacity. No matter that it hurts, you have to work because you know that there is a pile of CVs waiting in the office. There are plenty of Lithuanians who sleep on the floor waiting to get a job. So, there is this pressure that you have to keep up to get a contract for one, two, three months. So that eventually, they would give you a longer one so that you can...[do] something more... bring your child or save some money.

\section{Informant 11, female, 30s, 7 years in the industry}

The foregoing extract illustrates how the strong competition between migrants arriving at the municipality requires sacrifices, including of personal and family well-being. The narratives of

\footnotetext{
${ }^{4}$ According to the Norwegian Working Environment Act (2020) that regulates the relationship between employers and employees in Norway, part-time workers who during the previous twelve months have regularly worked in excess of the agreed number of hours are entitled to a post equivalent to the actual working hours during this period unless the employer can document that the additional work is no longer needed. The twelve-month period is to be calculated on the basis of the date that the employee submitted his or her claim.
} 
the migrants suggest that the increasing supply of labour allowed the employer to be fussier when selecting the workers he desired (see also Findlay and McCollum, 2013) which increased the competition amongst the migrants for employment. The willingness to stay and pursue lifeprojects amidst the competition led migrants to employ various strategies. In this case, the informant and her husband had decided to leave their child in the care of a grandparent in their home country whilst they were establishing themselves in the company; this arrangement resulted in significant emotional distress.

\section{Implications of the ethnically segmented workplace}

Studies have suggested that the structural properties of rural labour markets contribute to the segmentation of the migrants in rural communities (Lever and Milbourne, 2017; Moore, 2021). Our interviewees described the work at the plant as highly segmented and as separating them effectively from Norwegians working in the company (see also Stachowski, 2020). Such a situation, however, developed gradually. When the old plant was in operation, the proportion of foreign-born and Norwegian-born workers was more balanced. In the new facilities, however, the total number of workers had increased and the Norwegian-born workers had nearly all moved to other tasks such as administration, canteen, or cleaning, or had retired. With hardly any Norwegians on the shop-floor, the plant had become an assortment of many nationalities working next to each other on the production lines.

The imbalance between the foreign and Norwegian workers was noted by the interviewees who were highly aware that they constituted a distinct segment of the company's personnel. Not only were they separated from the Norwegian workers but they also experienced being treated differently from them. One informant claimed: "when you are a foreigner, you can feel that you are worthless compared to Nonwegians (...) through the treatment, the negligence of all your rights by the employer," referring to mistreatment through misguidance and the withholding of information about migrant workers' rights.

To manage a multi-ethnic workforce, the company recruited' instead middle managers from amongst the migrants whilst retaining Norwegian managers at the top of the chain of command. Whilst this strategy seemed to resolve the communication issues and ensure the workflow, it also increased the internal competition among the migrants. As described by a female worker with long tenure:

As for people from other countries (managers)... they show no respect. Irrespective of how hard you try, they always say that you don't do a good job (...). Lithuanians have started to rule the workplace. It was much friendlier in the beginning when the plant was relatively small and many Nonwegians were working there.

Interviewer: So, what else has changed since you have been there?

People didn't walk over dead bodies to achieve what they wanted... Norwegians are pretty calm, relaxed, easy-going. But here it is just stress. People are nervous, they scream and I don't like that.

Informant 15, woman, 40s, over ten years in the industry

The result of filling the management positions with persons recruited from amongst the migrants has resulted in the development of a work culture that diverges from the Norwegian one. Other studies have shown that network-based recruitment may work as a double-edged sword, satisfying the demand of the employers, but simultaneously giving rise to the establishment of national groupings and social closures (Piso, 2016). Here, however, in the case of a multinational workforce, it may also give rise to competition between the respective nationalities.

The divided workplace has had implications for the acquisition and practice of the Norwegian language on the part of the migrants. Many interviewees described their struggle to achieve a rudimentary level of Norwegian, even after many years of living in Norway. Discussing language practice, the migrants have frequently referred to it as ambiguous, underscoring its importance in ensuring functionality and overall well-being in Norway, but simultaneously claimed that it was irrelevant in the context of the segmented workplace: 
There is no pressure at the workplace to learn Norwegian. And the job does not motivate you to learn (...). You get the impression that there are several measures to teach you Norwegian, that the company (wants you to know Norwegian) (...) but that is only on paper. It is non-existent. The profit is what counts (for the employer). You are not an individual in the company, just someone who can be replaced.

\section{Informant 23, man, 30s, 10 years in the industry}

The demand for skills in Norwegian was problematic since it has been rendered almost irrelevant by the highly segregated organisation of work. The upshot of clustering migrants around manual tasks on the production line and the upward-mobility of native workers into administrative and office positions have resulted in segregating the workers by language. As such, it has had a significant negative effect on the migrants' opportunities to develop their skills in Norwegian. According to the participants, communication at work often took place in one of three languages: Norwegian, English, or Russian, or in a specific slang which was a hybrid of these three languages. It is important to mention that, in Norway, migrants from the EU are not entitled to free-of-charge language training but are obliged to learn Norwegian all the same (Directorate of Integration and Diversity, 2018). It is up to the municipalities to decide whether they want to provide language training to the labour migrants. In our case, the company offered both a mandatory, introductory language course and a voluntary one. However, these courses were ranked as poor by the migrants, primarily due to their low pedagogical level and the subsequent lack of opportunities to practice Norwegian.

\section{Concluding remarks}

The restructuring of rural economies resulting from increasing globalisation constitutes an important backdrop for the international migration to rural areas (Corrado et al. 2016; Rye and O'Reilly, 2021). In this article, we have analysed the case of post-accession labour migration to the booming Norwegian farmed salmon industry to cast light on the relationship between employment relations in rural industries and the inclusion of the international migrants in rural areas. Our goal has been to understand how the development of the industry and changing employment relations have affected the migrants' perceptions of their lives, well-being, and opportunities locally.

Whilst our findings resonate in many ways with earlier studies on the situation of international migrants in rural industries (see, for example, Piso, 2016; Rye, 2018; Lever and Milbourne, 2017), our main contribution has been to demonstrate the changing conditions for the reception of migrants within the local industry. We have shown how the early migrant workers experienced being welcomed as valuable workers through a social contract at work that extended beyond the obligations regulated in the formal, written employment agreement (see also Rousseau, 1995). However, as the number of migrants to the locality increased exponentially in response to the growth and expansion of the company, employment relations deteriorated. The most important changes were the introduction of a longer, more demanding and insecure trial period followed by an offer of only $80 \%$ of a full-time permanent position.

The changing employment relations are concomitant with the continued inflow of migrants offering seemingly unlimited access to foreign labour for the salmon industry. We have shown how the company's employment practices created conditions for flexibility in production (see also Ollus, 2016), but resulted in insecurity for the migrants about their situation. The sense of insecurity has been augmented by increased competition between the migrant workers for opportunities and permanent contracts, keeping them on their toes, disciplining them to consent and obedience, whilst they try to pursue their life goals. As a result, migrants have experienced being treated primarily as workers whose valuable assets are physical capability, endurance and unconditional willingness to work. The practice of being offered only $80 \%$ positions after having proven their capability was interpreted by the migrant workers as a breach of the social contract at work (see also Rousseau, 1995). It has been perceived as a discriminatory and exploitative practice, signalling that the migrants are considered disposable labour-power. This arrangement increased the vulnerability of the migrants and was perceived as transferring the risks of economic 
downturns and contingencies from the employer to the workers (Kalleberg, 2013). These experiences contrasted the narratives of the earlier arrived migrants who experienced paternalistic management and a social contract at work that extended beyond the sphere of work and workplace (Rouseeau, 1995). Our case illustrates that insecure conditions may emerge in a situation of direct employment, generally considered as more secure than indirect employment (Rye and Scott, 2018).

Successful inclusion of migrants both nationally and locally depends on a supportive and welcoming climate of reception (Bock et al,. 2016). Our analysis shows a change in employment relations from welcoming and valuing the migrants as a resource to a gradually more instrumental and impersonal treatment as 'working hands' that can be disposed of and replaced by other 'hands'. Whilst our study has focused exclusively on the standpoint of the migrants, it speaks to recent findings amongst employers in the Norwegian fish-processing industry that document their intention to prevent migrants from acquiring a "Norwegian work culture", including knowing their rights and being able to use them (Friberg and Midtbøen, 2017). Whilst such adaptations indicate tendencies towards migrants' integration, they may be at odds with the employers' interests. This suggests that a precondition of the profitability of employing migrants is their lack of adaptation. Our findings complement those findings, showing how migrants subjectively interpret being treated systematically differently from Norwegians, and how such practices deliberately impede their inclusion. Furthermore, the $80 \%$ positions have a symbolic dimension, signifying the incompleteness of their inclusion in both the local community and the Norwegian society at large.

It must be noted that, compared with the evidence of working conditions provided by the literature on international rural migration, the case analysed here is not amongst the most precarious ones. At the same time, Hardy (2017) reminds us that the degree of precarity should be considered within its specific national context and, in this context, it raises questions about the treatment of migrant workers in a very profitable Norwegian industry.

We would like to end with a reflection concerning the implications of our analysis for a better understanding of the connection between international migration and rural communities. Whilst, in the case of labour migrants, multiple factors beyond the sphere of work may affect their intentions to stay in rural areas (Flynn and Kay, 2017; Lynnebakke, 2020), this study shows that work and employment relations are of fundamental importance. Our findings add nuance to the 'demographic refill' thesis that views international migrants as central for the revitalisation of the rural communities and for ensuring their longevity (Hedberg and Haandrikman, 2014). Whilst our findings complement this argument, they also articulate clearly how, within a short period, the rural receiving context may change. They suggest that the initial 'refill' may reach a threshold and turn into what may be called 'demographic saturation'. It means that once the sustainability of the local industry is secured by a certain number of migrants, the subsequent migration may be regarded as surplus, the function of which is to satisfy purely economic needs. As such, it may contribute to generate or deepen class differences both within the rural communities and internally within groups of migrants, as it offers different conditions for different 'waves' of migrants. The case of permanent migration discussed here, as well as our one-sided focus on the migrants' standpoints, impose certain limitations on the proposed 'demographic saturation' thesis. Further studies could explore it from the perspective of other rural contexts and relevant actors, most notably local employers and long-term residents of rural communities. Ultimately, such studies could advance our comprehension of the long-term dynamics of rural social change propelled by international migration.

\section{Acknowledgements}

The authors would like to thank Bettina Bock, Emmanuelle Helio, Johan Fredrik Rye, Karen O'Reilly and the two anonymous reviewers for their valuable commentaries on the earlier versions of this article. 
[1] Aure, M., Førde, A. \& Magnussen, T. (2018). Will migrant workers rescue rural regions? Challenges of creating stability through mobility. Journal of Rural Studies 60, 52-59. DOI: 10.1016/j.jrurstud.2018.03.005.

[2] Barth, E., Moene, K. O. \& Willumsen, F. (2014). The Scandinavian model - An interpretation. Journal of Public Economics 117, 60-72. DOI: 10.1016/j.jpubeco.2014.04.001.

[3] Bayona-i-Carrasco, J. \& Gil-Alonso, F. (2013). Is Foreign Immigration the Solution to Rural Depopulation? The Case of Catalonia (1996-2009). Sociologia Ruralis 53(1), 26-51. DOI: 10.1111/j.1467-9523.2012.00577.x.

[4] Bock, B. B. \& Osti, G. (2016). Rural Migration and New Patterns of Exclusion and Integration in Europe. In Shucksmith, M. \& Brown, D. L., eds., Routledge International Handbook of Rural Studies (pp. 71-84). London: Routledge.

[5] Bygnes, S. \& Erdal, M. B. (2017). Liquid migration, grounded lives: considerations about future mobility and settlement among Polish and Spanish migrants in Norway. Journal of Ethnic and Migration Studies 43(1), 102-118. DOI: 10.1080/1369183X.2016.1211004.

[6] Burawoy, M. (1976). The Functions and Reproduction of Migrant Labor: Comparative Material from Southern Africa and the United States. American Journal of Sociology (81), 1050-1087. DOI: 10.1086/226185.

[7] Castles, S. \& Kosack, G. (1972). The Function of Labour Immigration in Western European Capitalism. New Left Review 73, 3-21.

[8] Corrado, A., De Castro, C. \& Perrotta, D. (2016). Migration and agriculture: Mobility and change in the Mediterranean area. London: Routledge. DOI: $10.4324 / 9781315659558$.

[9] de Lima, P. (2012). Boundary Crossings: Migration, Belonging/'Un-belonging' in Rural Scotland. In Hedberg, C. \& do Carmo, R. M., eds., Translocal Ruralism: Mobility and Connectivity in European Rural Spaces (pp. 203-217). Dordrecht: Springer. DOI: 10.1007/978-94-007-2315-3_12.

[10] de Lima, P. \& Wright, S. (2009). Welcoming Migrants? Migrant Labour in Rural Scotland. Social Policy and Society 8(3), 391-404. DOI: 10.1017/s1474746409004941.

[11] Décosse, F. (2016). Persistent unfree labour in French intensive agriculture. A historical overview of the "OFIl" temporary farmworkers program. In Corrado, A., de Castro, C. \& Perotta, D., eds., Migration and Agriculture. Mobility and change in the Mediterranean (pp. 183-197). Oxon, New York: Routledge.

[12] Dufty-Jones, R. (2014). Rural Economies in the 'Age of Migration': Perspectives from OECD Countries. Geography Compass 8(6), 368-380. DOI: 10.1111/gec3.12130..

[13] Fiałkowska, K. (2019). Remote fatherhood and visiting husbands: seasonal migration and men's position within families. Comparative Migration Studies 7, Art. 2, DOI: 10.1186/s40878-018-0106-2.

[14] Findlay, A. \& McCollum, D. (2013). Reqruitment and employment regimes : Migrant labour channels in the UK's rural agrubusiness sector, from accession to recession. Journal of Rural Studies 30, 10-19. DOI: 10.1016/j.jrurstud.2012.11.006.

[15] Findlay, A., McCollum, D., Shubin, S., Apsite, E. \& Krisjane, Z. (2013). The role of recruitment agencies in imagining and producing the "good" migrant. Social \& Cultural Geography 14(2), 145-167. DOI: 10.1080/14649365.2012.737008.

[16] Flynn, M. \& Kay, R. (2017). Migrants' experiences of material and emotional security in rural Scotland: Implications for longer-term settlement. Journal of Rural Studies, 52, 56-65. DOI: 10.1016/j.jrurstud.2017.03.010. 
[17] Friberg, J. H. (2012a). Culture at work: Polish migrants in the ethnic division of labour on Norwegian construction sites. Ethnic and Racial Studies 35(11), 1914-1933. DOI: $10.1080 / 01419870.2011 .605456$.

[18] Friberg, J. H. (2012b). The Stages of Migration. From Going Abroad to Settling Down: PostAccession Polish Migrant Workers in Norway. Journal of Ethnic and Migration Studies 38(10), 1589-1605. DOI: 10.1080/1369183X.2012.711055.

[19] Friberg, J. H. (2016). Arbeidsmigrasjon. Hva het vi om konsekvensene for norsk arbeidsliv, samfunn og økonomi? Oslo: Fafo.

[20] Friberg, J. F. \& Eldring, L. (2013). Labour migrants from Central and Eastern Europe in the Nordic countries. Patterns of migration, working conditions and recruitment practices. Copenhagen: Nordic Council of Ministers. DOI: 10.6027/tn2013-570.

[21] Friberg, J. H. \& Midtbøen, A. H. (2018). Ethnicity as skill: immigrant employment hierarchies in Norwegian low-wage labour markets. Journal of Ethnic and Migration Studies 44(9), 1463 1478. DOI: $10.1080 / 1369183 X .2017 .1388160$.

[22] Green, A. E., de Hoyos, M., Jones, P. \& Owen, D. (2009). Rural development and labour supply challenges in the UK: The role of non-UK migrants. Regional Studies 43(10), $1261-$ 1273. DOI: $10.1080 / 00343400801932318$.

[23] Gmaj, K. (2016). Settling in Norway? The Case of Polish Migrants and their Familes. Myśl Ekonomiczna i Polityczna 53(2), 163-191.

[24] Gouldner, A. W. (1960). The norms of reciprocity: A preliminary statement. American Sociological Review 25, 161-178. DOI: 10.2307/2092623.

[25] Grzymała-Kazłowska, M. \& Phillimore, J. (2019). Superdiversity and Its Relevance for Central and Eastern European Migration Studies. The Case of Polish Migrants in the UK. Central and Eastern European Migration Review 8(2), 39-59. DOI: 10.17467/ceemr.2019.16.

[26] Hardy, J. A. (2017). Re-conceptualizing precarity: institutions, structure and agency. Employee Relations 39(3), 263-273. DOI: 10.1108/ER-06-2016-0111.

[27] Hedberg, C. \& do Carmo, R. M. (2012). Translocal Ruralism: Mobility and Connectivity in European Rural Spaces. Springer. DOI: 10.1007/978-94-007-2315-3_1.

[28] Hedberg, C. \& Haandrikman, K. (2014). Repopulation of the Swedish countryside: Globalisation by international migration. Journal of Rural Studies 34, 128-138. DOI: 10.1016/j.jrurstud.2014.01.005.

[29] Holmes, S. M. (2013). Fresh Fruits, Broken Bodies. Migrant Farmworkers in the United States. Berkeley, Los Angeles, London: California Series in Public Anthropology.

[30] Jentsch, B. (2007). Migrant Integration in Rural Areas Evidence from New Countries of Immigration. International Journal on Multicultural Societies 9(1), 1-12.

[31] Jentsch, B. \& Simard, M. (2009). International migration and rural areas: Cross-national comparative perspectives. Contemporary Sociology: A Journal of Reviews 39(4), 501. DOI: $10.1177 / 0094306110373351 \mathrm{n}$.

[32] Kalleberg, A. (2013). Good Jobs, Bad Jobs. The Rise of Polarized and Precarious Employment Systems in the United States, 1970s to 2000s. New York: Russel Sage Foundation.

[33] Knight, J., Lever, J. \& Thompson, A. (2014). The Labour Market Mobility of Polish Migrants: A Comparative Study of Three Regions in South Wales, UK. Central and Eastern European Migration Review 3(2), 61-78.

[34] Lever, J. \& Milbourne, P. (2017). The Structural Invisibility of Outsiders: The Role of Migrant Labour in the Meat-Processing Industry. Sociology 51(2), 306-322. DOI: $10.1177 / 0038038515616354$. 
[35] Lynnebakke, B. (2020). 'I felt like the mountains were coming for me.' - The role of place attachment and local lifestyle opportunities for labour migrants' staying aspirations in two Norwegian rural municipalities. Migration Studies 1-24, DOI: 10.1093/migration/mnaa002.

[36] McAreavey, R. (2017). New immigration destinations: Migrating to rural and peripheral areas. Abingdon: Routledge. DOI: 10.1201/9780415540056.

[37] MacKenzie, R. \& Forde, C. (2009). The rhetoric of the 'good worker' versus the realities of employers' use and the experiences of migrant workers. Work Employment Society 23(1), 142-159. DOI: $10.1177 / 0950017008099783$.

[38] McGhee, D., Heath, S. \& Trevena, P. (2012). Dignity, happiness and being able to live a 'normal life' in the UK e an examination of post-accession Polish migrants' transnational $\begin{array}{llll}\text { autobiographical fields. } \quad \text { Social } & \text { Identities } & 18(6), & \end{array}$ DOI: 10.1080/13504630.2012.709002.

[39] Moore, H. (2021). Perceptions of Eastern European migrants in an English village: the role of the rural place image. Journal of Ethnic and Migration Studies 47(1), 267-283. DOI: 10.1080/1369183X.2019.1623016.

[40] Morén-Alegret, R. \& Wladyka, D. (2020). International Immigration, Integration and Sustainability in Small Towns and Villages. London: Palgrave Macmillan. DOI: 10.1057/9781-137-58621-6.

[41] Nieswand, B. (2011). Theorising Transnational Migration. The Status Paradox of Migration. New York, Abingdon: Routledge.

[42] Ollus, N. (2016). Forced Flexibility and Exploitation: Experiences of Migrant Workers in the Cleaning Industry. Nordic Journal of Working Life Studies 6(1), 25-45. DOI: 10.19154/njwls.v6i1.4908.

[43] Pajnik, M. (2016). 'Wasted precariat': Migrant work in European societies. Progress in Development Studies 16(2), 159-172. DOI: 10.1177/1464993415623130.

[44] Piętka-Nykaza, E. \& McGhee, D. (2017). EU post-accession Polish migrants trajectories and their settlement practices in Scotland. Journal of Ethnic and Migration Studies 43(9), 14171433. DOI: $10.1080 / 1369183 X .2016 .1241137$.

[45] Piore, M. J. (1979). Birds of Passage. Cambridge Univeristy Press. DOI: $10.1017 / \mathrm{cbo9780511572210.}$

[46] Piso, A. (2016). Migrant Labour in Rural Tourism: Continuity and Change. International Journal of Tourist Research 18, 10-18. DOI: 10.1002/jtr.2020.

[47] Rabikowska, M. (2010). Negotiation of normality and identity among migrants from Eastern Europe to the United Kingdom after 2004. Social Identities, Journal of the Study of Race, Nation and Culture 3(16), 285-296. DOI: 10.1080/13504630.2010.482391.

[48] Rasmussen, B. \& Håpnes, T. (2012). Permanent Temporariness? Changes in Social Contracts in Knowledge Work. Nordic Journal of Working Life Studies 2(1), 5-22. DOI: https://doi.org/10.19154/njwls.v2i1.2349.

[49] Recchi, E. \& Triandafyllidou, A. (2010). Crossing Over, Heading West and South. Mobility, Citizenship, and Employment in the Enlarged Europe. In: Menz, G. \& Caviedes, A. Labour Migration in Europe (pp. 127-149). London: Palgrave Macmillan.

[50] Roberts, B. (2002). Biographical Research. London: Open University Press.

[51] Rousseau, D. (1995). Psychological Contracts in Organizations. Thousand Oaks: Sage.

[52] Rye, J. F. (2018). Labour migrants and rural change: The "mobility transformation" of Hitra/Frøya, Norway, 2005-2015. Journal of Rural Studies 64, 189-199. DOI: 10.1016/j.jrurstud.2017.12.003.

[53] Rye, J. F. \& Scott, S. (2018). International Labour Migration and Food Production in Rural Europe: A Review of the Evidence. Sociologia Ruralis 58(4), 928-952. 
DOI: $10.1111 /$ soru. 12208.

[54] Rye, J. F. \& Scott, S. (2021). Agricultural employers' representation and rationalisation of their work offer: the 'benevolent moderator'. In: Rye, J. F. \& O'Reilly, K., eds., International Labour Migration to Europe's Rural Regions (pp. 141-158). Abingdon: Routledge.

[55] Rye, J. F. \& Slettebak, M. H. (2020). The new geography of labour migration: EU11 migrants in rural Norway. Journal of Rural Studies 75, 125-131. DOI: 10.1016/j.jrurstud.2020.01.014.

[56] Rye, J. F. \& O'Reilly, K. (2021). International Labour Migration to Europe's Rural Regions. Abingdon: Routledge.

[57] Ryndyk, O. (2020). The role of labour market integration in migrants' decisions about family reunification: a comparative study of Polish migrants in Norway, Sweden, and the UK. Comparative Migration Studies 8, Art. 17. DOI: 10.1186/s40878-020-00177-2.

[58] Sayad, A. (2004). The Suffering of the Immigrant. Cambridge (UK), Malden (MA): Polity Press Ltd.

[59] Scott, S. (2013). Labour, migration and the spatial fix: Evidence from the UK food industry. Antipode 45(5), 1090-1109. DOI: 10.1111/anti.12023.

[60] Scott, S. \& Brindley, P. (2012) New geographies of migrant settlement in the UK. Geography 97(1), 29-38. DOI: 10.1080/00167487.2012.12094334.

[61] Sert, D. (2018). The Diversification of Intra-European Movement. In: Scholten, P. \& van Ostaijen, M., eds., Between Mobility and Migration. The Multi-Level Governance of IntraEuropean Movement (pp. 21-43). Cham: Springer. DOI: 10.1007/978-3-319-77991-1_2.

[62] Smith, V. (1998) The Fractured World of the Temporary Worker: Power, Participation and Fragmentation in the Contemporary Workplace. Social Problems 45(4), 411-430. DOI: $10.2307 / 3097205$.

[63] Stachowski, J. (2020). Processes of socio-spatial exposures and isolations among Polish labour migrants in rural Norway: Exploring social integration as a lived experience. European $\begin{array}{llll}\text { Urban and Regional 379-397. } & \text { Studies, }\end{array}$ DOI: https://doi.org/10.1177/0969776420930758.

[64] Stachowski, J. \& Fiałkowska, K. (2021). 'Living on the edge'? a comparative study of processes of marginalisation among Polish migrants in rural Germany and Norway. In: Rye, J. F. \& O'Reilly, K., eds., International Labour Migration to Europe's Rural Regions. (pp. 104120). Abingdon: Routledge.

[65] Standing, G. (2011). The Precariat. The New Dangerous Class. London: Bloomsbury Academic.

[66] Søholt, S, Aasland, A., Onsager, K. \& Vestby, G. M. (2012). «Derfor blir vi her»- innvandrere i Distriks-Norge [research report]. Oslo: Norsk Institutt for by- og regionforskning.

[67] Vandenberg, P. (2015). Ensuring the Triple Win of Labour Migrants in Asia [Policy Brief]. Tokyo: Asian Development Bank Institute.

[68] Woods, M. (2007). Engaging the global countryside: Globalization, hybridity and the reconstitution of rural place. Progress in Human Geography 31(4), 485-507. DOI: $10.1177 / 0309132507079503$.

[69] Woods, M. (2018). Precarious rural cosmopolitanism: Negotiating globalization, migration and diversity in Irish small towns. Journal of Rural Studies 64, 164-176. DOI: 10.1016/j.jrurstud.2018.03.014.

Other sources

[70] Directorate of Integration and Diversity (2018). Norskopplæring. Retrived from: https://www.imdi.no/norskopplaring/. 
[71] International Labour Organization (2016). Non-standard employment around the world. Understanding challenges, shaping prospects. International labour Office. Geneva. Retrieved from:https://www.ilo.org/wcmsp5/groups/public/---dgreports/---dcomm/--publ/documents/publication/wcms_534496.pdf.

[72] Statistics Norway (2020). Innvandrere og norskfødte med innvandrerforeldre.

Statistikkbanken. Retrieved from:

https://www.ssb.no/statbank/table/05183/tableViewLayout1/.

[73] The Norwegian Labour Inspection Authority (2020). Minimum wages. Retrieved from: https://www.arbeidstilsynet.no/en/working-conditions/pay-and-minimum-rates-ofpay/minimum-wage/.

[74] Work Environment Act (2020). Retrived from: https://lovdata.no/dokument/NLE/lov/2005-0617-62\#KAPITTEL_2. 